\title{
Soil physical restrictions and hydrology regulate stand age and wood biomass turnover rates of Purus-Madeira interfluvial wetlands in
} \section{Amazonia}

\author{
B. B. L. Cintra ${ }^{1,2}$, J. Schietti ${ }^{1}$, T. Emillio ${ }^{1}$, D. Martins ${ }^{1}$, G. Moulatlet ${ }^{1}$, P. Souza ${ }^{1}$, C. Levis ${ }^{1}$, C. A. Quesada ${ }^{1}$, and \\ J. Schöngart ${ }^{1,2}$ \\ ${ }^{1}$ Instituto Nacional de Pesquisas da Amazônia (INPA), Manaus, Amazonas, Brazil \\ ${ }^{2}$ Max Planck Institute for Chemistry, Biogeochemistry Department, Mainz, Germany
}

Correspondence to: B. B. L. Cintra (biomail.bruno@gmail.com)

Received: 6 January 2013 - Published in Biogeosciences Discuss.: 5 April 2013

Revised: 21 October 2013 - Accepted: 23 October 2013 - Published: 29 November 2013

\begin{abstract}
In Amazonia, wetlands constitute about $30 \%$ of its entire basin, of which ancient fluvial terraces located in vast interfluvial regions cover a large portion. Although the increased number of permanent plots in the recent years has contributed to improved understanding of regional variation in forest dynamics across the Amazon Basin, the functioning of large lowland interfluvial wetlands remain poorly understood. Here we present the first field-based estimate for tree ages, wood biomass productivity and biomass turnover rates for eight 1 ha plots in wetland and non-flooded forests distributed along the BR-319 Highway along a distance of about $600 \mathrm{~km}$ crossing the Purus-Madeira rivers interfluvial region in central-southwestern Amazon Basin. We estimate stand age, wood biomass productivity and biomass turnover rates combining tree-ring data and an allometric equation based on diameter, tree height and wood density and relate these structural parameters to physical soil and hydrological restrictions. Wood biomass and productivity varied twofold among the plots, with wood biomass stocks ranging between $138-294 \mathrm{Mg} \mathrm{ha}^{-1}$ and productivity varying between 3.4-6.6 Mg ha-1 $\mathrm{yr}^{-1}$. Soil effective depth, topography, structure and mainly soil water saturation significantly affected stand age (64-103 yr) and forest dynamics in terms of annual biomass turnover rates (2.0-3.2\%). On harsher soils characterized by a poor structure, low effective depth and high water saturation, biomass turnover rates were increased and forests stands were younger compared to welldrained sites. We suggest that soil constraints, especially soil water saturation, limit the development of the stand struc-
\end{abstract}

ture, resulting in forests with younger stand ages and higher biomass turnover rates compared to forests growing on welldrained soils. We do not find, however, any relation between physical soil restrictions or hydrology and wood biomass productivity, but there is a trend of increasing wood biomass productivity and phosphorus concentrations at the soil surface. Based on our results we establish hypotheses for different dynamical processes between forests growing on waterlogged and well-drained soils and discuss how these results can be applied in the background of conservation as well as the potential development of forest management plans in this region, which will experience increased deforestation due to the construction of the BR-319 Highway crossing the interfluvial region of the Purus-Madeira rivers.

\section{Introduction}

About two million square kilometers of the Amazon Basin falls under wetland classification criteria (Junk et al., 2011). Although the increased number of permanent plots in recent years has contributed to improved understanding of regional variation in forest dynamics across the Amazon Basin (Baker et al., 2004; Malhi et al., 2004; Girardin et al., 2010), most of the studies on forest dynamics focus on non-flooded terra firme forests. Only a few studies focus on forest dynamics of wetland forests such as the seasonally flooded forests along large rivers, mostly in terms of wood productivity (see Schöngart et al., 2010). Other types of forested wetlands, 
such as large interfluvial wetlands which are found along vast regions in the central and western Amazonia (Sombroek, 2001), are poorly studied and understood.

Little is known about how environmental factors such as soil conditions, climate and hydrology control forest dynamics in interfluvial wetlands. In these ecosystems soil drainage and the depth of the water table vary considerably, creating a patchwork of seasonally flooded or waterlogged and nonflooded forests. This process often leads to the formation of a firm plinthite layer that can change to hardpan if exposed to repeated wetting and drying cycles (Quesada et al., 2011). Therefore, the presence of soil physical constraints, such as the depth to which tree roots penetrate and the presence of restriction layers (e.g., hardpans) may be very important for stand development. In this study we focus on how the heterogeneous and complex hydrology and soil properties influence stand development and forest dynamics.

Forest dynamics expressed in terms of productivity, tree mortality and turnover rates is known to be affected by edaphic and/or climatic disturbances. Soil physical properties are determinant for tree turnover rates (Quesada et al., 2012), while soil fertility, especially phosphorous (P) status, is related with wood productivity (Malhi et al., 2004; Quesada et al., 2012). However, the responses of forest dynamics to climate vary between forest types (Schöngart et al., 2010). In non-flooded terra firme forests diameter growth is strongly related to seasonal precipitation (Brienen and Zuidema, 2005) and severe droughts negatively affect forest dynamics, decreasing wood biomass productivity and increasing tree mortality (Foley et al., 2002; Phillips et al., 2009; Corlett et al., 2011; Lewis et al., 2011). In contrast, the seasonal inundation of floodplain forests of the central Amazonia leads to a reduction of diameter growth (Schöngart et al., 2002), and an enhanced tree growth during the nonflooded period can be attributed to El Niño-induced droughts, since the terrestrial phase is extended during El Niño years compared to other years (Schöngart et al., 2004; Schöngart and Junk, 2007).

In this study we use tree-ring analysis showing how stand development may be affected by varying conditions of hydrology and soil physical constraints along the PurusMadeira rivers interfluvial region in the central-southwestern Amazonia. In this region smooth topographic variations result in contrasting soil physical and hydrological conditions at local scale. We expect that forests on well-drained soils present a higher wood biomass productivity and wood biomass turnover than sites characterized by waterlogged, anoxic soils. The presented results are the first field-based estimates for tree ages, wood biomass productivity and biomass turnover rates in this vast interfluvial landscape. As predicted by future deforestation scenarios, the region will suffer huge impacts as a consequence of human occupation following the re-paving of the BR-319 Highway planned by the Brazilian Government (Laurance et al., 2001; Soares-Filho et al., 2006; Fearnside et al., 2009; Davidson et al., 2012). We discuss the

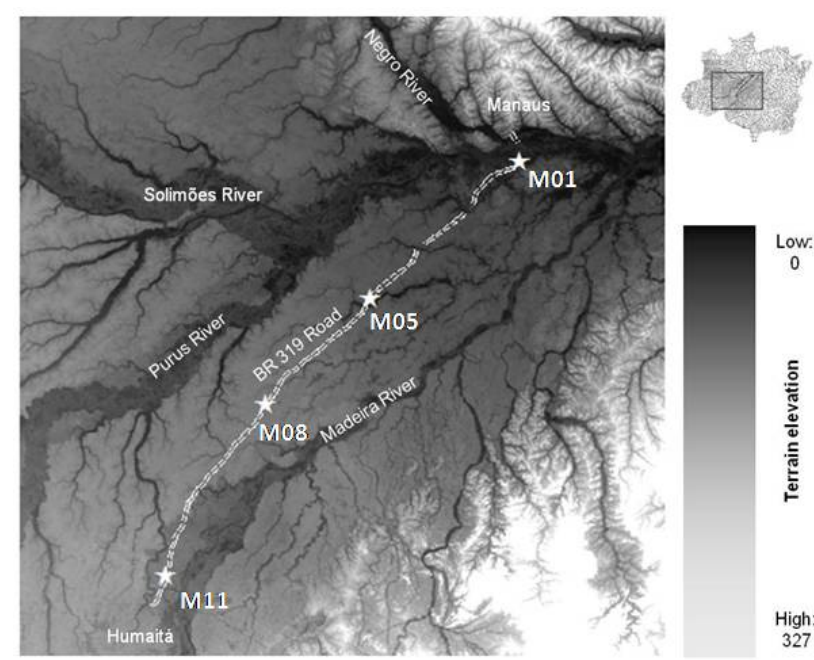

Fig. 1. Map of the Purus-Madeira interfluvial area that is crossed by the BR-319 Highway. The study sites are indicated by white asteriks. All study sites are sampling modules (M) of the PRONEXProject "Rapid Assessment for Long Duration Ecological Projects" (RAPELD).

application of the obtained scientific data on wood productivity, stand age and biomass turnover and their relationship to environmental conditions in the background of the sustainable development of the region to discriminate between areas for strict conservation or management priorities.

\section{Material and methods}

\subsection{Study region}

The study was carried out in the interfluvial region of the Purus-Madeira rivers in the Amazonas state, Brazil, that is intersected by the BR-319 Highway connecting the cities of Manaus and Porto Velho, the capitals of the Amazonas and Rondônia states, respectively (Fig. 1). The dominant vegetation type in the northern part of this region is dense lowland rainforests, while in the south a transition towards open lowland rainforests occurs, probably caused by increasing rainfall seasonality (IBGE, 1997). The predominant soil type for the whole interfluvial region is Plinthosol/Gleysol (Martins et al., 2013). On a local scale, frequent variations in the topography of a few meters create temporary pools on the lower and poorly drained areas during the rainy season (Rosetti et al., 2005). The duration and intensity of the rainy season varies strongly from north to south along the interfluvial area, declining from 2800 to $2100 \mathrm{~mm}$ annual precipitation with increasing rainfall seasonality (Table 1). 


\subsection{Sampling design}

A total of eleven research modules of the PRONEX project "Rapid Assessment for Long Duration Ecological Projects" (RAPELD) was established along the Purus-Madeira interfluvial region as part of the research module network of the Research Program in Biodiversity (PPBio, http://ppbio. inpa.gov.br/sitios/br319). For this study, we selected four out of the eleven modules (Table 1). The average distance between the modules was $140-200 \mathrm{~km}$, spanning an approximately $600 \mathrm{~km}$ distance (Fig. 1). In each module we choose two of the ten 1 ha $(250 \times 40 \mathrm{~m})$ permanent plots previously installed: one at the highest altitude (well-drained) and the other plot at the lowest topography (poorly drained), using SRTM-DEM data (Shuttle Radar Thematic Mapper Digital Elevation Model, NASA Jet Propulsion Laboratory, US Geological Survey) (Miranda, 2005; Farr et al., 2007). Each plot followed an isocline to minimize variation in the topography and soil conditions within a plot (Magnusson et al., 2005). The RAPELD program records all trees with diameter at breast height $(\mathrm{DBH})$ above $30 \mathrm{~cm}$ in the installed 1 ha plots. Trees with a DBH of $10-29.9 \mathrm{~cm}$ are considered on two $10 \mathrm{~m}$-large sections on both sides of the $250 \mathrm{~m}$-long transect in the middle of the plot (0.5 ha) (Magnusson et al., 2005).

\subsection{Soil data}

Soil samples of $30 \mathrm{~cm}$ depth were extracted with an auger every $50 \mathrm{~m}$ along the central $250 \mathrm{~m}$-long transect in all plots, totaling six samples per plot, and kept in sealed plastic bags for 2-5 days. On arrival at the laboratory, the samples were air dried at ambient temperature and composite samples were prepared, resulting in one sample per plot. Soil texture was then analyzed following standard protocol of total dispersion using sodium pyrophosphate to obtain clay, sand and silt percentages (Donagema et al., 2011). Chemical analysis concentration was also analyzed, following the protocol by Donagema et al. (2011). Soil physical constraints in each plot were scored using the classification index of Quesada et al. (2010) (Table 2), using soil samples of $2 \mathrm{~m}$ depth collected by the HIDROVEG project (http://ppbio.inpa.gov.br/sitios/ br319). Additionally pits of $2 \mathrm{~m}$ depth were dug in modules M01, M05 and M08 for detailed soil descriptions. Soil physical constraints classified by Quesada's index are based on the effective depth of the soil (i.e. maximum depth that roots can attain), topography, soil structure and density as well as anoxic/hydromorphic properties. Anoxic condition (Table 2) is referred to in the present study as water saturation index. This index may be an important edaphic parameter as it appears to be related to vegetation parameters (Martins et al., 2013), and can be easily scored by identification of redox features at different depths. Superficial phosphorus concentration and soil water saturation index scores were available for all 55 plots spread in eleven modules in the whole interfluvial region. All soil samples were collected in cooperation with the HIDROVEG and RAINFOR project and analyzed at the Thematic Soils Laboratory of the National Institute for Amazon Research (INPA).

\subsection{Topographical and hydrological conditions}

The plots were preselected, based on SRTM data to capture a wide range of topographies within and between the selected modules. Afterwards we applied the Height Above the Nearest Drainage model (HAND) based on SRTM data that indicated the vertical distance of the plot in relation to the nearest water-table as an indicator for the hydrological conditions (Rennó et al., 2008; Moulatlet, 2010). We also used the soil water saturation index (Table 2) to indicate the terrain's hydrological condition. The difference between this index and the height above the nearest drainage is that the HAND data describe hydrology based on topography, and therefore will be most effective in terrains with pronounced topographical variations, since the level of the groundwater table may vary with the elevation depending on the soil conditions. The water saturation index, on the other hand, is based on soil features that were developed by long-term underground water fluctuations, such as patches of oxidation/reduction reactions and formation of plinthite hardpans (see Quesada et al., 2010), and is therefore a more reliable indicator for variations in soil water saturation of the study sites.

\subsection{Field measurements}

We considered all trees with DBH $>30 \mathrm{~cm}$ in the forest inventory (Schietti, 2013) in order to obtain data on wood densities as well as to estimate ages and diameter increment rates for each tree by tree-ring analysis. Trees with $\mathrm{DBH}>30 \mathrm{~cm}$ were selected in ascending order of their numbers in the inventory, in order to select trees spread along the plot. Further, we sampled 30 randomly selected trees within the DBH classes $10-29.9 \mathrm{~cm}$ in each plot. Palm trees (Arecaceae) were not considered in this study, since they do not present tree rings. In the studied plots palm trees comprise $9.8 \pm 7.9 \%$ of all individuals and $10.2 \pm 8.2 \%$ of the total basal area.

The DBH of all trees was measured by a diameter tape. In case of buttresses, diameter was measured above them to avoid overestimates of basal area and wood biomass. Tree height was estimated using a height measurement device (Blume Leiss BL6) and meter tapes to measure the distance between the tree and the observer. Two wood samples were extracted from the trunk of each tree $10 \mathrm{~cm}$ below the DBH $(120 \mathrm{~cm}$ above the forest floor) to avoid errors for future repeated diameter measurements with the aim to monitor forest dynamics, using an increment borer of $5.15 \mathrm{~mm}$ internal diameter. On buttressed trees, coring was done between the buttresses whenever was possible, to avoid sampling biased rings. When it was not possible, the buttressed tree was not sampled. One sample was extracted for wood density determination and was labeled and stored in closed plastic 
Table 1. Geographical position, hydrology and rainfall patterns of the selected study sites. Elevation above sea level (a.s.l.) is estimated by SRTM data (Shuttle Radar Topographic Mission). Data of the HAND model (Height Above Nearest Drainage) indicate the distance and elevation above the nearest drainage (Rennó et al., 2008); number in parenthesis indicates the flood height of seasonally inundated forests measured in the field. Soil water saturation conditions are described and presented in more detail in Table 2. Rainfall data were obtained from the Brazilian Water Agency (Agência Nacional de Águas - ANA). Length of dry season refers to number of months with less than 100 mm of rainfall.

\begin{tabular}{|c|c|c|c|c|c|c|c|}
\hline Plot ID & Plot Coordinates & $\begin{array}{r}\text { Elevation } \\
\text { (m a.s.1.) }\end{array}$ & $\begin{array}{r}\text { Elevation } \\
\text { above } \\
\text { nearest } \\
\text { drainage }(\mathrm{m})\end{array}$ & $\begin{array}{r}\text { Distance } \\
\text { from } \\
\text { nearest } \\
\text { drainage }(\mathrm{m})\end{array}$ & $\begin{array}{l}\text { Soil water } \\
\text { saturation } \\
\text { condition }\end{array}$ & $\begin{array}{r}\text { Mean } \\
\text { annual } \\
\text { rainfall } \\
(\mathrm{mm})\end{array}$ & $\begin{array}{r}\text { Length } \\
\text { of dry } \\
\text { season } \\
\text { (months) }\end{array}$ \\
\hline M01-TN1500 & $\begin{array}{r}3^{\circ} 21^{\prime} 3.73^{\prime \prime} \mathrm{S}, \\
59^{\circ} 50^{\prime} 48.78^{\prime \prime} \mathrm{W}\end{array}$ & 35.5 & $1.0(1.5)$ & 145 & $\begin{array}{l}\text { Seasonally } \\
\text { flooded }\end{array}$ & \multirow{2}{*}{2300} & \multirow{2}{*}{3} \\
\hline M01-TN2500 & $\begin{array}{r}3^{\circ} 20^{\prime} 55.27^{\prime \prime} \mathrm{S}, \\
59^{\circ} 50^{\prime} 14.58^{\prime \prime} \mathrm{W}\end{array}$ & 32.2 & $3.0(5.0)$ & 324 & $\begin{array}{l}\text { Seasonally } \\
\text { flooded }\end{array}$ & & \\
\hline M05-TN(-)500 & $\begin{array}{r}4^{\circ} 36^{\prime} 58.05^{\prime \prime} \mathrm{S}, \\
61^{\circ} 14^{\prime} 37.44^{\prime \prime} \mathrm{W}\end{array}$ & 48.9 & 3.3 & 519 & $\begin{array}{l}\text { Seasonally } \\
\text { saturated }\end{array}$ & \multirow{2}{*}{2810} & \multirow{2}{*}{2} \\
\hline M05-TN1500 & $\begin{array}{r}4^{\circ} 36^{\prime} 11.82^{\prime \prime} \mathrm{S}, \\
61^{\circ} 15^{\prime} 28.10^{\prime \prime} \mathrm{W}\end{array}$ & 50.0 & 2.0 & 11 & $\begin{array}{l}\text { Non-flooded - deep } \\
\text { saturated zone }\end{array}$ & & \\
\hline M08-TS2500 & $\begin{array}{r}5^{\circ} 38^{\prime} 18.54^{\prime \prime} \mathrm{S}, \\
62^{\circ} 10^{\prime} 41.24^{\prime \prime} \mathrm{W}\end{array}$ & 69.4 & 3.4 & 175 & $\begin{array}{l}\text { Non-flooded - deep } \\
\text { saturated zone }\end{array}$ & \multirow{2}{*}{2600} & \multirow{2}{*}{3} \\
\hline M08-TS4500 & $\begin{array}{l}5^{\circ} 38^{\prime} 51.38^{\prime \prime} \mathrm{S} \\
62^{\circ} 9^{\prime} 45.25^{\prime \prime} \mathrm{W}\end{array}$ & 66.6 & 3.5 & 332 & $\begin{array}{l}\text { Non-flooded - deep } \\
\text { saturated zone }\end{array}$ & & \\
\hline M11-TN1500 & $\begin{array}{c}7^{\circ} 12^{\prime} 24.72^{\prime \prime} \mathrm{S}, \\
63^{\circ} 7^{\prime} 0.29^{\prime \prime} \mathrm{W}\end{array}$ & 72.8 & 3.8 & 141 & $\begin{array}{l}\text { Non-flooded - deep } \\
\text { saturated zone }\end{array}$ & \multirow{2}{*}{2100} & \multirow{2}{*}{4} \\
\hline M11-TN2500 & $\begin{array}{l}7^{\circ} 12^{\prime} 38.37^{\prime \prime} \mathrm{S}, \\
63^{\circ} 6^{\prime} 30.52^{\prime \prime} \mathrm{W}\end{array}$ & 69.8 & 1.6 & 128 & $\begin{array}{l}\text { Permanently } \\
\text { saturated }\end{array}$ & & \\
\hline
\end{tabular}

bags to avoid dehydration for three to nine days before analyzing. The second sample was glued on labeled wooden supports for later tree-ring analysis. All wood samples were transported to the Dendroecological Laboratory of the scientific cooperation between INPA and MPIC (Max Planck Institute for Chemistry) in Manaus for further analyses.

\subsection{Botanical data}

All listed species were identified by Priscila Souza and Carolina Levis. After a preliminary identification, the botanical determination was confirmed with the aid of specialists, field guides and by comparing the collected vouchers with specimens at the INPA herbarium (Manaus, Brazil) and virtual herbariums (http://sciweb.nybg.org/science2/vii2.asp). Fertile specimens were deposited at INPA and sterile material will be stored in an adjacent working collection. Plants were identified in accordance with the APG III (Angiosperm Phylogenetic Group III) classifications. For name correction of the taxa the Brazilian Flora Species List was consulted (http://floradobrasil.jbrj.gov.br/2012/).

\subsection{Biomass and carbon stock estimates}

Information on the total basal area and number of individuals per hectare for the diameter classes $10-29.9 \mathrm{~cm}$ and above $30 \mathrm{~cm}$ was obtained from forest inventory data (Schietti, 2013). Since trees in the RAPELD program protocol with DBH of 10-29.9 cm are sampled only on 0.5 ha (Magnusson et al., 2005), information on basal area for this diameter class was multiplied by factor two to obtain estimates for the entire hectare. To calculate wood density $(\rho)$ the fresh volume $\left(V_{\text {fresh }}\right)$ of each sample was determined by the water displacement method. The object is mounted on a needle and immersed into a recipient filled with water on an analytic balance calibrated to zero. The volume (in $\mathrm{mL}$ ) of the object is equal to the indicated weight (in $\mathrm{g}$ ) of the displaced water after submerging the object entirely into the water without touching the side or the bottom of the recipient. After this step of analysis the samples were dried at a temperature of $105^{\circ} \mathrm{C}$ to obtain their dry weight $\left(W_{\text {dry }}\right)$ (Chave et al., 2005; Schöngart et al., 2005). Wood specific density was than calculated as

$\rho=W_{\text {dry }} / \mathrm{V}_{\text {fresh }}$.

For each plot we calculated the mean wood density and standard deviation. Since there are no specific allometric models available for the studied forest types we chose an allometric model that uses diameter, tree height and wood density as independent parameters to enhance the quality of the AGWB estimates (Chave et al., 2004, 2005; Schöngart et al., 2010, 2011). This way we may reduce any biases caused by possible differences in tree height and wood density among the areas, that can be expected over large distances (Chave et al., 2005; Wittmann et al., 2006; Nogueira et al., 2008a, b; 
Table 2. Score table for physical soil constraints (withdrawn and adapted from Quesada et al., 2010). Anoxic conditions were referred to as "water saturation index" in the present study.

\begin{tabular}{|c|c|}
\hline Soil physical constraints rating categories & Score \\
\hline \multicolumn{2}{|l|}{ Effective soil depth (soil depth, hardpans) } \\
\hline Shallow soils (less than $20 \mathrm{~cm}$ ) & 4 \\
\hline Less shallow $(20$ to $50 \mathrm{~cm})$ & 3 \\
\hline Hardpan or rock that allows vertical root growth; other soils between 50 and $100 \mathrm{~cm}$ deep & 2 \\
\hline Hardpan, rocks or $\mathrm{C}$ horizon $\geq 100 \mathrm{~cm}$ deep & 1 \\
\hline Deep soils $\geq 150 \mathrm{~cm}$ & 0 \\
\hline \multicolumn{2}{|l|}{ Soil structure } \\
\hline Very dense, very hard, very compact, without aggregation, root restrictive & 4 \\
\hline Dense, compact, little aggregation, lower root restriction & 3 \\
\hline Hard, medium to high density and/or with weak or block-like structure & 2 \\
\hline Loose sand, slightly dense; well aggregated in sub-angular blocks, discontinuous pans & 1 \\
\hline Good aggregation, friable, low density & 0 \\
\hline \multicolumn{2}{|l|}{ Topography } \\
\hline Very steep $>45^{\circ}$ & 4 \\
\hline Steep $20^{\circ}$ to $44^{\circ}$ & 3 \\
\hline Gentle undulating $8^{\circ}$ to $19^{\circ}$ & 2 \\
\hline Gentle sloping $1^{\circ}$ to $8^{\circ}$ & 1 \\
\hline Flat $0^{\circ}$ & 0 \\
\hline \multicolumn{2}{|l|}{ Anoxic conditions } \\
\hline Constantly flooded; patches of stagnated water & 4 \\
\hline Seasonally flooded; soils with high clay content and very low porosity and/or dominated by plinthite & 3 \\
\hline Deep saturated zone (maximum height of saturation $50 \mathrm{~cm}$ depth); redox features & 2 \\
\hline Deep saturated zone (maximum height of saturation $>100 \mathrm{~cm}$ depth); deep redox features & 1 \\
\hline Unsaturated conditions & 0 \\
\hline
\end{tabular}

Feldpausch et al., 2011) due to vegetation type shifts from the north to the south within the interfluvial region. We used the model developed by Feldpausch et al. (2012) (Eq. 2), reporting the relative error estimated by the authors for the use of power law regional model for estimating tree height. For the equation described below, the parameters are referred to as aboveground coarse wood biomass (AGWB, in kg), diameter at breast height (DBH, in $\mathrm{cm})$, tree height $(\mathrm{H}$, in $\mathrm{m})$, and wood density $\left(\rho\right.$, in $\left.\mathrm{g} \mathrm{cm}^{-3}\right)$.

$\mathrm{AGWB}=\exp \cdot\left(-2.9205+0.9894 \cdot \ln \left(H \cdot \mathrm{DBH}^{2} \cdot \rho\right)\right)$

As not all trees of the plot were sampled we estimate the AGWB in relation to the basal area of the sampled trees. This was performed separately for the two diameter classes $\mathrm{DBH}>30 \mathrm{~cm}(>30)$ and trees with DBH 10-29.9 cm $(<30)$. For this study we assume that the carbon content $\left(\mathrm{C}_{\%}\right)$ in the AGWB is about $47 \%$ (Kirby and Potvin, 2007).

\subsection{Tree-ring analysis and growth modeling}

We used tree-ring analysis to obtain reliable estimates for tree ages and mean diameter growth rates which have successfully been applied to estimate wood biomass productivity in different forest types of central Amazonia (Worbes, 1997; Stadtler, 2007; Oliveira, 2010; Schöngart et al., 2010) and also in the Pantanal wetlands (Schöngart et al., 2011). The prepared wood samples for tree-ring analysis were sanded and polished to produce a plain surface that enabled the visualization of the annual rings based on macroscopic wood anatomical analysis. Wood anatomy of tree rings was characterized following Worbes (2002) (Fig. 2). The anatomy of tropical wood may generate uncertainties due to indistinct, false or missing rings that cannot be detected when analyzing $5.15 \mathrm{~mm}$ cores. These uncertainties are reduced when considering the average of large number of rings for estimating mean radial increment and productivity. Since we use only the last five rings to estimate tree productivity, samples with indistinct tree rings were not included in the estimate of aboveground wood biomass productivity (AGWBP).

Ring widths were measured using a digital measuring device (LINTAB) with $0.01 \mathrm{~mm}$ precision attached to a computer with the software Time Series Analysis and Presentation (TSAP-WIN) to determine mean radial increments (Schöngart et al., 2005). On samples which contained the pith, tree age was estimated by direct ring count. For samples with missing pith we estimated tree age by dividing the obtained average diameter increment rates by the measured DBH in the field. The mean tree age per plot was calculated as the average of the ages from all sampled trees 


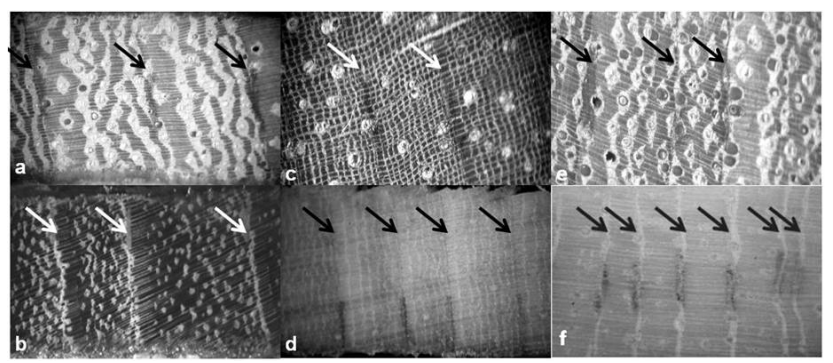

Fig. 2. Examples of distinct tree rings. The classification of wood anatomy of the tree rings is described following Worbes (2002). (a, b) Parenchyma bands limiting ring boundaries and vessel size/distribution variation from earlywood to latewood; (c, d) alternating fiber and parenchyma bands, large in the earlywood and narrow in the latewood; $(\mathbf{e}, \mathbf{f})$ marginal parenchyma bands limiting the tree rings. Arrows indicate the boundary of the tree rings.

with $\mathrm{DBH}>30 \mathrm{~cm}$ and with DBH of $10-29.9 \mathrm{~cm}$, weighted by their relative number of individuals $\left(\operatorname{Ind}_{>} 30\right.$ and $\left.\operatorname{Ind}_{<30}\right)$ in the plot:

$\mathrm{AGE}_{\mathrm{PLOT}}=\left(\mathrm{AGE}_{>30} \cdot \frac{\mathrm{Ind}_{>30}}{\operatorname{Ind}_{\text {total }}}\right)+\left(\mathrm{AGE}_{<30} \cdot \frac{\mathrm{Ind}_{<30}}{\operatorname{Ind}_{\text {total }}}\right)$

where $\mathrm{AGE}_{>30}$ and $\mathrm{AGE}_{<30}$ represent the average of the ages calculated per diameter class, Ind $_{>30}$ and Ind $_{<30}$ represent the number of individuals per diameter class in the plot and Ind $_{\text {total }}$ represent the number of all individuals with $\mathrm{DBH}>10 \mathrm{~cm}$ in the plot.

Non-linear regressions were carried out between DBH and tree height using potential equations to produce DBH-height relationships for each plot and module. The relationship between tree age and DBH was fitted to non-linear regression models (Schöngart, 2008):

$\mathrm{AGE}_{\text {tree }}=a \cdot e^{-b \mathrm{DBH}}$.

\subsection{Estimation of stand wood biomass productivity and biomass turnover rates}

To estimate the AGWBP the cumulative diameter growth curve of a tree was combined with the stand-specific DBHheight regression model and the wood density to calculate AGWB by the allometric model of Eq. (2) for every year of the entire life span of the tree (Schöngart et al., 2011). We then estimated the current aboveground wood biomass productivity of each tree $\left(\mathrm{AGWBP}_{\text {tree }}\right)$ calculating the average of the difference between the AGWB for the last five consecutive years $(t)$ (Eq. 5):

$\mathrm{AGWBP}_{\text {tree }}=\sum\left(\mathrm{AGWB}_{t}-\mathrm{AGWB}_{t-5}\right) / 5$,

where $t$ is the year corresponding to the last ring formed by the tree. As not all trees of the plot were considered for this analysis we estimated the productivity in relation to the basal area for all sampled trees to indicate the current total productivity of the plot. This was performed separately for the two diameter classes $\mathrm{DBH}>30 \mathrm{~cm}(>30)$ and trees with $\mathrm{DBH}$ $10-29.9 \mathrm{~cm}(<30)$ (Eq. 6).

$\mathrm{AGWBP}=\left(\mathrm{AGWB}_{>30} \cdot \frac{\mathrm{BA}_{\text {Total }}}{\mathrm{BA}_{>30}}+\mathrm{AGWB}_{<30} \cdot \frac{\mathrm{BA}_{\text {Total }}}{\mathrm{BA}_{<30}}\right)$

Biomass turnover rates in percentage were calculated by dividing AGWBP by AGWB for each plot:

Turnover $_{\text {biomass }}=\left(\frac{\mathrm{AGWBP}}{\mathrm{AGWB}}\right) \cdot 100$.

Data on stand age, biomass turnover and wood productivity were related to the scored physical constraints indexes using linear regressions (Quesada et al., 2010), considering that the referred indices are semi-categoric. Data analysis and graphs were performed using R (R-Core Development Team, 2013) software packages stats and graphics.

\section{Results}

\subsection{Forest structure}

A total of 554 trees were cored in the eight 1 ha plots, from which 20 individuals were not considered for tree-ring analysis due to very low distinction of the growth rings. The sampling effort of coring per plot was 47 to 87 trees with $\mathrm{DBH}>30 \mathrm{~cm}$ per hectare, corresponding to $53-96 \%$ of all individuals in this diameter class (Table 3 ). Tree height was measured for a total of 627 trees, as well as DBH. Tree diameter explained $56-62 \%$ of the variability in tree height (Fig. 3), with exception of module M08 where the multiple R-squared was only $0.31(p<0.01)$ (Fig. 3c).

Among the most abundant tree species wood density varied from $0.44 \pm 0.11 \mathrm{~g} \mathrm{~cm}^{-3}$ (Apeiba echinata) to $0.90 \pm 0.05 \mathrm{~g} \mathrm{~cm}^{-3}$ (Licania oblongifolia) (Table 4). Mean wood density of the 20 individuals that were not considered for tree-ring analysis due to very low distinction of the tree rings was $0.49 \mathrm{~g} \mathrm{~cm}^{-3}$ and $0.46 \mathrm{~g} \mathrm{~cm}^{-3}$ in plots M01_TN_1500 and M11_TN_1500, respectively, and varied between $0.68 \mathrm{~g} \mathrm{~cm}^{-3}$ and $0.84 \mathrm{~g} \mathrm{~cm}^{-3}$ in the other plots. Only one individual was not considered in the plot M11_TN_2500, with a wood density of $0.91 \mathrm{~g} \mathrm{~cm}^{-3}$.

The seasonally flooded sites at M01 presented a much lower basal area $\left(16-17 \mathrm{~m}^{2} \mathrm{ha}^{-1}\right)$ compared to the other sites (21-28 $\mathrm{m}^{2} \mathrm{ha}^{-1}$ ) (Table 3). We also observed lower canopy heights $(24-25 \mathrm{~m})$ and lower mean wood densities (0.64$0.65 \mathrm{~g} \mathrm{~cm}^{-3}$ ) in the seasonally flooded forests of M01 compared to the other sites with canopy heights of $25-28 \mathrm{~m}$ and mean wood densities of $0.65-0.72 \mathrm{~g} \mathrm{~cm}^{-3}$.

\subsection{Tree ages, radial increment, forest productivity and biomass turnover}

Maximum estimated tree age based on counted tree rings including pith was $214 \mathrm{yr}$. Another individual presented 239 
Table 3. Number of sampled trees from the diameter classes $10.0-29.9 \mathrm{~cm}$ and $>30 \mathrm{~cm}$ in each plot. Stand structure is described by basal area as well as by means and standard deviation of canopy height and wood density. Estimates of AGWB and C-stocks in AGWB and the structural conversion factor $\left(\mathrm{AGWB}_{\mathrm{SCF}}\right.$ related to $\mathrm{m}^{2}$ basal area); $\sigma_{\mathrm{AGWB}}$ indicates the error of the AGWB estimate. Furthermore for each plot, information on aboveground coarse wood productivity (AGWBP) and carbon sequestration per hectare and year (C-sequestration) are indicated, as well as the annual biomass turnover. The soil conditions are indicated by the soil physical constraints and the soil water saturation indices (see Table 2 for scoring).

\begin{tabular}{|c|c|c|c|c|c|c|c|c|}
\hline \multicolumn{9}{|c|}{ Plot ID } \\
\hline & $\begin{array}{r}\text { M01- } \\
\text { TN1500 }\end{array}$ & $\begin{array}{r}\text { M01- } \\
\text { TN2500 }\end{array}$ & $\begin{array}{r}\text { M05- } \\
\text { TN(-)500 }\end{array}$ & $\begin{array}{r}\text { M05- } \\
\text { TN1500 }\end{array}$ & $\begin{array}{r}\text { M08- } \\
\text { TS2500 }\end{array}$ & $\begin{array}{r}\text { M08- } \\
\text { TS4500 }\end{array}$ & $\begin{array}{r}\text { M11- } \\
\text { TN1500 }\end{array}$ & $\begin{array}{r}\text { M11- } \\
\text { TN2500 }\end{array}$ \\
\hline \multicolumn{9}{|l|}{ Number of cored trees } \\
\hline DBH $10.0-29.9 \mathrm{~cm}$ & 29 & 33 & 27 & 24 & 25 & 25 & 28 & 27 \\
\hline $\mathrm{DBH}>30 \mathrm{~cm}$ & 38 & 36 & 43 & 38 & 47 & 37 & 43 & 34 \\
\hline \multicolumn{9}{|l|}{ Structural features } \\
\hline Basal area $\left(\mathrm{m}^{2} \mathrm{ha}^{-1}\right)$ & 16 & 17 & 22 & 27 & 25 & 28 & 24 & 21 \\
\hline Mean canopy height (m) & $25 \pm 4.5$ & $24 \pm 3.9$ & $27 \pm 5.0$ & $28 \pm 4.0$ & $28 \pm 5.9$ & $25 \pm 5.3$ & $32 \pm 7.9$ & $27 \pm 4.9$ \\
\hline Mean wood density $\left(\mathrm{g} \mathrm{cm}^{-3}\right)$ & $0.65 \pm 0.15$ & $0.64 \pm 0.13$ & $0.72 \pm 0.14$ & $0.71 \pm 0.16$ & $0.68 \pm 0.13$ & $0.67 \pm 0.12$ & $0.65 \pm 0.14$ & $0.67 \pm 0.16$ \\
\hline Stand age (years) & 75 & 64 & 90 & 103 & 100 & 94 & 96 & 65 \\
\hline $\operatorname{AGWB}\left(\mathrm{Mg} \mathrm{ha}^{-1}\right)$ & 138 & 136 & 229 & 291 & 274 & 278 & 294 & 205 \\
\hline$\sigma_{\mathrm{AGWB}}\left(\mathrm{Mg} \mathrm{ha}^{-1}\right)$ & -16.6 & -16.3 & -27.5 & -34.9 & -32.8 & -33.4 & -35.2 & -24.6 \\
\hline C-stock AGWB $\left(\mathrm{Mg} \mathrm{ha}^{-1}\right)$ & 65 & 64 & 108 & 137 & 129 & 131 & 138 & 96 \\
\hline $\mathrm{AGWB}_{\mathrm{SCF}}\left(\mathrm{Mg} \mathrm{m}_{\mathrm{BA}}^{-2}\right)$ & 8.6 & 7.9 & 10.4 & 10.7 & 11.1 & 10.0 & 12.3 & 10.0 \\
\hline $\operatorname{AGWBP}\left(\mathrm{Mg} \mathrm{ha}^{-1} \mathrm{yr}^{-1}\right)$ & 4.0 & 3.4 & 5.5 & 6.5 & 5.6 & 5.9 & 6.2 & 6.6 \\
\hline $\mathrm{C}$-sequestration $\left(\mathrm{Mg} \mathrm{ha}^{-1} \mathrm{yr}^{-1}\right)$ & 1.9 & 1.6 & 2.6 & 3.1 & 2.6 & 2.8 & 2.9 & 3.1 \\
\hline Biomass turnover $(\%)$ & 2.9 & 2.5 & 2.4 & 2.2 & 2.0 & 2.1 & 2.1 & 3.2 \\
\hline \multicolumn{9}{|l|}{ Soil conditions } \\
\hline Soil physical constraints index & 10 & 10 & 8 & 8 & 4 & 7 & 7 & 10 \\
\hline Soil water saturation index & 3 & 3 & 3 & 2 & 1 & 2 & 2 & 4 \\
\hline
\end{tabular}

Table 4. Mean value and standard deviation of wood density $(\rho)$ and mean radial increments (MRI) for characteristic tree species with five or more individuals in the study sites.

\begin{tabular}{lrr}
\hline Tree species & $\rho\left(\mathrm{g} \mathrm{cm}^{-3}\right)$ & $\mathrm{MRI}\left(\mathrm{mm} \mathrm{yr}^{-1}\right)$ \\
\hline Apeiba echinata Gaertn. & $0.44 \pm 0.11$ & $3.4 \pm 2.4$ \\
Bertholletia excelsa Bonpl. & $0.61 \pm 0.04$ & $1.6 \pm 0.6$ \\
Brosimum rubescens Taub. & $0.56 \pm 0.08$ & $1.9 \pm 0.4$ \\
Buchenavia grandis Ducke & $0.71 \pm 0.11$ & $2.2 \pm 0.8$ \\
Diplotropis martiusii Benth. & $0.66 \pm 0.10$ & $1.7 \pm 0.1$ \\
Ecclinusa guianensis Eyma & $0.69 \pm 0.09$ & $1.5 \pm 0.9$ \\
Erisma bicolor Ducke & $0.49 \pm 0.07$ & $2.3 \pm 1.2$ \\
Eschweilera truncata A. C. Sm. & $0.77 \pm 0.05$ & $1.5 \pm 0.5$ \\
Eschweilera coriacea (DC.) S. A. Mori & $0.81 \pm 0.07$ & $1.1 \pm 0.4$ \\
Goupia glabra Aubl. & $0.74 \pm 0.06$ & $2.5 \pm 1.8$ \\
Licania micrantha Miq. & $0.84 \pm 0.06$ & $1.4 \pm 0.1$ \\
Licania oblongifolia Standl. & $0.90 \pm 0.05$ & $1.3 \pm 0.5$ \\
Pouteria guianensis Aubl. & $0.79 \pm 0.15$ & $1.3 \pm 0.5$ \\
Pouteria virescens Baehni & $0.80 \pm 0.13$ & $1.3 \pm 0.4$ \\
Pseudolmedia laevis (Ruiz \& Pav.) J. F. Macbr. & $0.70 \pm 0.09$ & $1.1 \pm 0.2$ \\
Pterocarpus officinalis Jacq. & $0.77 \pm 0.11$ & $1.5 \pm 0.9$ \\
Scleronema micranthum (Ducke) Ducke & $0.54 \pm 0.09$ & $1.4 \pm 0.4$ \\
\hline
\end{tabular}



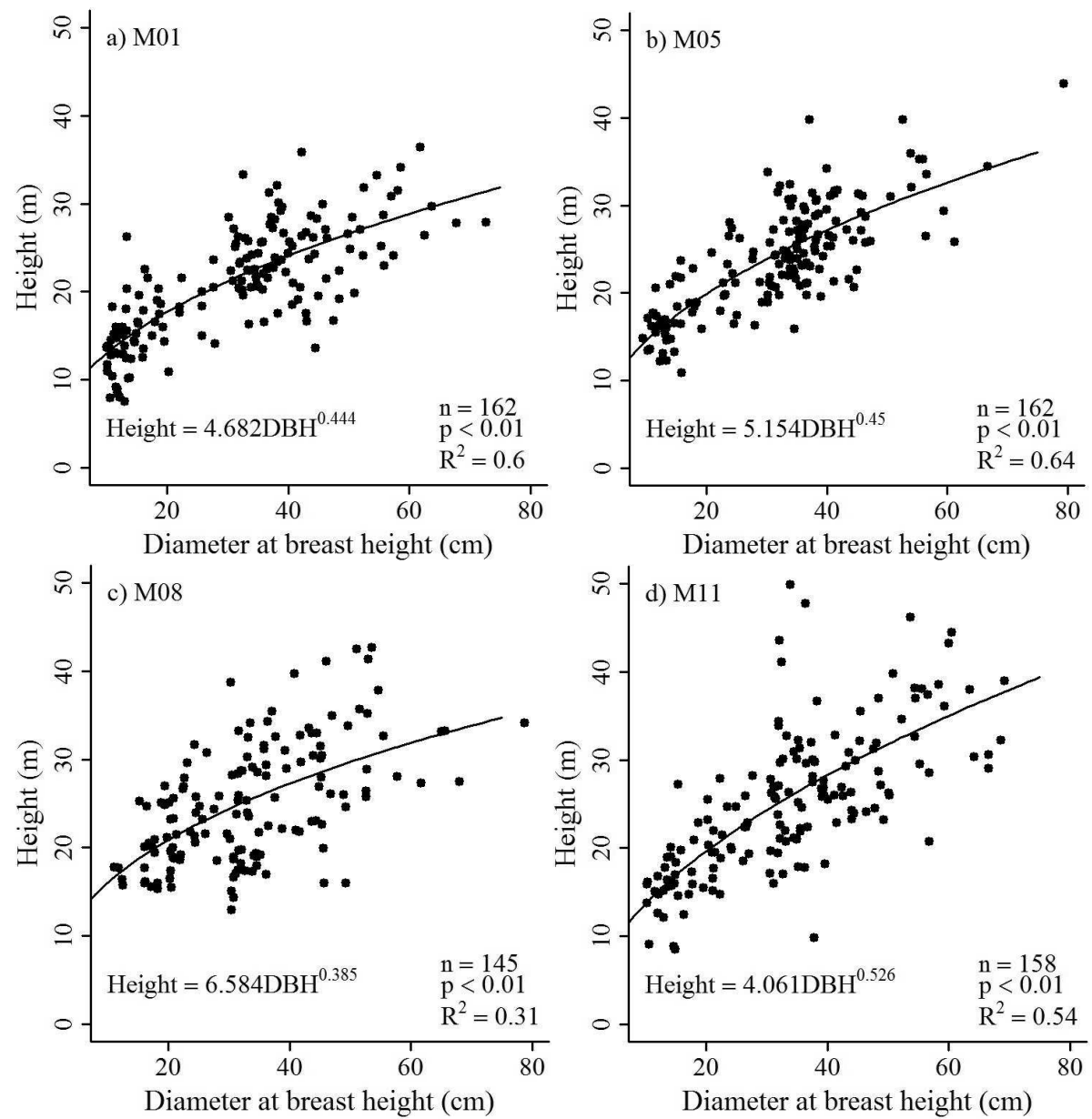

Fig. 3. Non-linear relationships between tree diameter at breast height and height. M01, M05, M08 and M11 represent each sampling module for which the models were developed.

rings without reaching the pith, resulting in an age estimate of more than $500 \mathrm{yr}$, extrapolating the mean radial increments in relation to the mean radius of the tree trunk. By this calculation, we estimated that from all the 534 analyzed trees, 33 would be more than $200 \mathrm{yr}$ old. The nonlinear relationship between DBH and tree age from all plots was significant $\left(n=534, d f=532, F=108.65, R^{2}=0.29\right.$, $p<0.01$ ) (Fig. 4a). However, the strength of correlation was not sufficient to consider the model as a predictor of tree ages in the field only by measuring DBH, independent of the species. Only about $30 \%$ of the variability of tree age among different species and varying growth condition can be explained by $\mathrm{DBH}$, due to differences in growth rates between species and individuals of the same species growing under different environmental conditions. The lowest mean annual radial increments were observed for Pseudolmedia laevis $\left(1.1 \pm 0.2 \mathrm{~mm} \mathrm{yr}^{-1}\right)$ and Eschweilera coriacea $\left(1.1 \pm 0.4 \mathrm{~mm} \mathrm{yr}^{-1}\right)$, while A. echinata presented radial increment rates of $3.4 \pm 2.4 \mathrm{~mm} \mathrm{yr}^{-1}$ (Table 4). On the stand level mean wood density was negatively related to the mean radial increments $\left(n=8, d f=7, F=11.12, R^{2}=0.65\right.$, $p<0.05)$ (Fig. 4b)

Estimates of AGWB resulted in $230 \mathrm{Mg} \mathrm{ha}^{-1}$ with a standard deviation of $65 \mathrm{Mgha}^{-1}$ for the whole study region (Table 3). The lower basal area, canopy height and mean wood density in the M01 stands resulted in lower AGWB estimates of $136-138 \mathrm{Mgha}^{-1} \mathrm{com}-$ pared to $205-291 \mathrm{Mgha}^{-1}$ at the other sites (Table 3). In relation to the basal area of the stand the AGWB

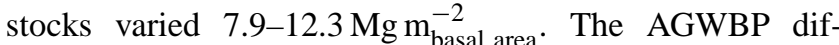
fered from $3.4 \mathrm{Mgha}^{-1} \mathrm{yr}^{-1}$ to $4.0 \mathrm{Mgha}^{-1} \mathrm{yr}^{-1}$ in the seasonally flooded forests of module M01 and was much higher in the other modules ranging between 5.5$6.6 \mathrm{Mg} \mathrm{ha}^{-1} \mathrm{yr}^{-1}$. The estimated C-sequestration varied between $1.6-1.9 \mathrm{MgC} \mathrm{ha}^{-1} \mathrm{yr}^{-1}$ in the seasonally flooded forests of module M01 and between $2.6-3.1 \mathrm{Mg} \mathrm{ha}^{-1} \mathrm{yr}^{-1}$ in the other plots. Biomass turnover varied between 2.0-3.2\% with higher turnover rates in the seasonally flooded and waterlogged sites (2.4-3.2\%) and lower rates at non-flooded, well-drained sites (2.0-2.2\%) (Table 3). The estimated stand 


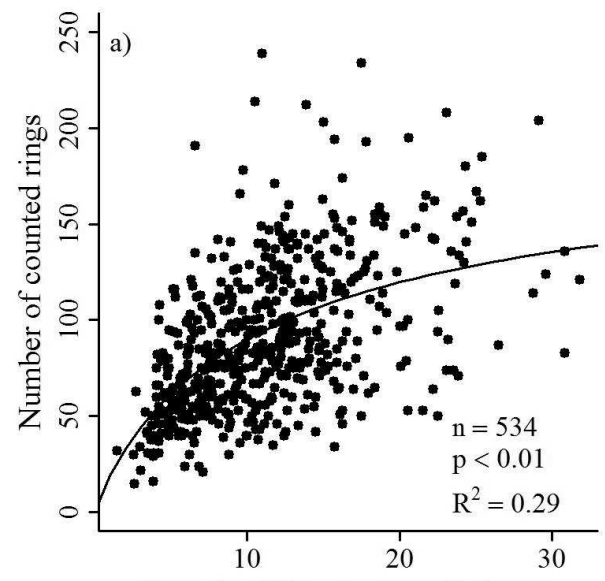

Length of the core sample ( $\mathrm{mm})$

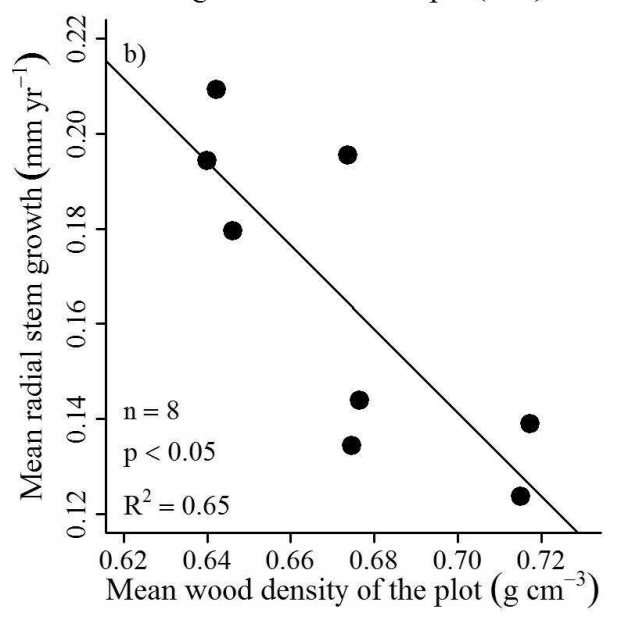

Fig. 4. (a) Significant non-linear relationship between the number of counted rings and length of the core samples for all analyzed trees with distinct growth rings and (b) significant correlation between estimated mean radial stem growth and mean wood density of the eight 1 ha plots.

age was lower at seasonally flooded and waterlogged sites (65-96 yr) compared to forests on well-drained sites (94$103 \mathrm{yr})$.

\subsection{Soil properties}

The soil texture of all plots was mainly composed of silt $(52.8 \pm 18.8 \%)$, with varying smaller percentages of sand $(27.7 \pm 15.7 \%)$ and clay $(19.4 \pm 6.0 \%)$ (Table 5). Available superficial phosphorus concentrations varied between 1.4 and $6.3 \mathrm{mg} \mathrm{g}_{\text {soil }}^{-1}$, with the higher values being found in the flooded forests of M01 which might be related to the seasonal inundation by river water. Iron concentration $\left(\mathrm{Fe}^{+}\right)$ranged from 66 to $389 \mathrm{mg} \mathrm{g}_{\text {soil. }}^{-1}$. The soil water saturation index varied at the seasonally flooded and waterlogged soils by 3-4 and in the well-drained soils by $1-2$. The scored soil physical constraint index varied in well-drained soils between 4 and 8 and reached and index of 8-10 in the seasonally flooded and waterlogged soils (Table 3).

\subsection{Relationship between forest dynamics and environmental conditions}

Forest dynamics, in terms of coarse wood biomass productivity, biomass turnover and stand age, is here hypothesized to vary with soil structure and hydrology. We found no relation between AGWBP and the scored soil physical constraints in$\operatorname{dex}\left(n=8, d f=6, R^{2}=0.15, F=1.04, p=0.34\right)$. On the other hand, the soil physical constraints index was positively related to biomass turnover rates (Fig. 5a) $(n=8, d f=6$, $\left.R^{2}=0.62, F=9.81, p<0.05\right)$ and negatively related to stand age (Fig. 5b) $\left(n=8, d f=6, R^{2}=0.64, F=10.92\right.$, $p<0.05$ ). Among all the soil features that compose the soil physical constraints index, the soil water saturation seems to be an important parameter, showing a strong relation with both biomass turnover and stand age. The soil water saturation index was positively related to the biomass turnover rates (Fig. 5c, $n=8, d f=6, R^{2}=0.79, F=23.31, p<0.01$ ) and negatively related to stand age (Fig. $5 \mathrm{~d}, n=8, d f=6, R^{2}=$ $0.70, F=13.71, p<0.01$ ). No significant relationships were found between the soil water saturation index and AGWBP ( $\left.n=8, d f=6, R^{2}=0.03, F=0.20, p>0.05\right)$.

We find no correlation between AGWBP, biomass turnover rates or stand age and parameters of soil texture and chemistry. However, since flooding at the M01 module is influenced by large river waters, soil chemical properties at M01 do not follow the same patterns as in other modules. Therefore, excluding the M01 plots, we noticed a very strong correlation between AGWBP and available phosphorus in the soil (Fig. 6a) ( $\left.n=, d f=4, R^{2}=0.77, F=13.21, p<0.05\right)$. We find no relation between the water saturation index and the phosphorus concentration in our plots, but on a regional scale, there is a positive correlation between the concentration of available phosphorus and the water saturation index (Fig. 6b, $n=42, d f=40, R^{2}=0.16, F=7.76, p<0.01$ ).

\section{Discussion}

The presented data on tree ages, diameter growth, wood biomass productivity and biomass turnover rates indicate stands of varying forest dynamics in the studied region. The AGWBP of the studied forests varies considerably between 3.4 and $6.6 \mathrm{Mg} \mathrm{ha}^{-1} \mathrm{yr}^{-1}$ (Table 3) and biomass turnover rates differ by more than $50 \%$ between the plots. We find that soil physical constraints considering soil depth, soil structure and soil water saturation significantly affect forest dynamics in the interfluvial landscape. Harsher soil physical conditions characterized by shallower effective depth, higher density and especially more water saturation, resulting in higher by constraint scores, enhance biomass turnover rates and forest dynamics, resulting in younger forest stands stocking on 
Table 5. Chemical and physical soil properties obtained from $30 \mathrm{~cm}$ depth of composited soil samples for each study site. Numbers in parentheses indicate values obtained for $10 \mathrm{~cm}$ soil depth.

\begin{tabular}{|c|c|c|c|c|c|c|c|}
\hline Plot_id & Clay (\%) & Coarse sand (\%) & Total sand (\%) & Fine sand $(\%)$ & Silt (\%) & $\mathrm{Fe}^{+}\left(\mathrm{mg} \mathrm{g}_{\text {soil }}^{-1}\right)$ & $P\left(\mathrm{mgg}_{\text {soil }}^{-1}\right)$ \\
\hline M01-TN1500 & 12.2 & 0.8 & 19.0 & 18.2 & 68.6 & 224.9 & 6.3 \\
\hline M01-TN2500 & 27.8 & 1.0 & 16.4 & 15.4 & 55.7 & 316.2 & 6.3 \\
\hline M05-TN(-)500 & 15.1 & 29.6 & 46.8 & 17.2 & 37.9 & 195.8 & 2.0 \\
\hline M05-TN1500 & $(20.0)$ & (1.4) & $(22.8)$ & (21.4) & $(57.1)$ & 312.5 & (3.1) \\
\hline M08-TS2500 & 17.0 & 1.0 & 19.7 & 18.7 & 63.2 & 388.8 & 1.4 \\
\hline M08-TS4500 & 14.6 & 0.7 & 17.9 & 17.2 & 67.5 & 139.6 & (2.0) \\
\hline M11-TN1500 & 28.4 & 26.8 & 58.3 & 31.5 & 13.2 & 136.2 & 2.2 \\
\hline M11-TN2500 & 19.7 & 0.4 & 20.9 & 20.4 & 59.3 & 66.7 & 2.8 \\
\hline
\end{tabular}
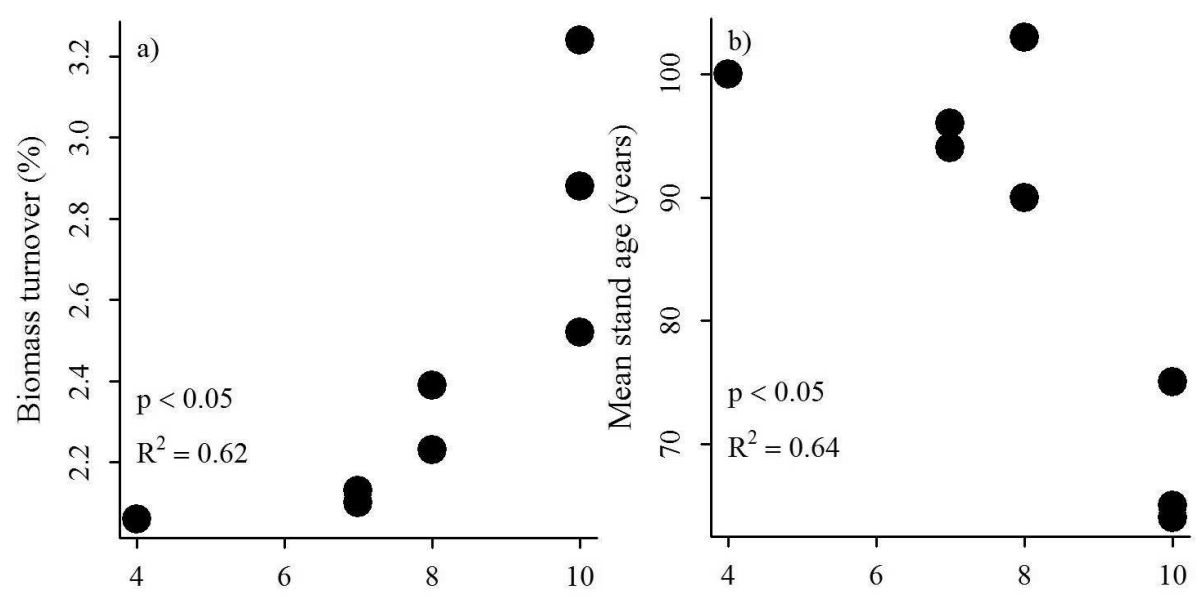

Scored soil physical constraints index

Scored soil physical constraints index
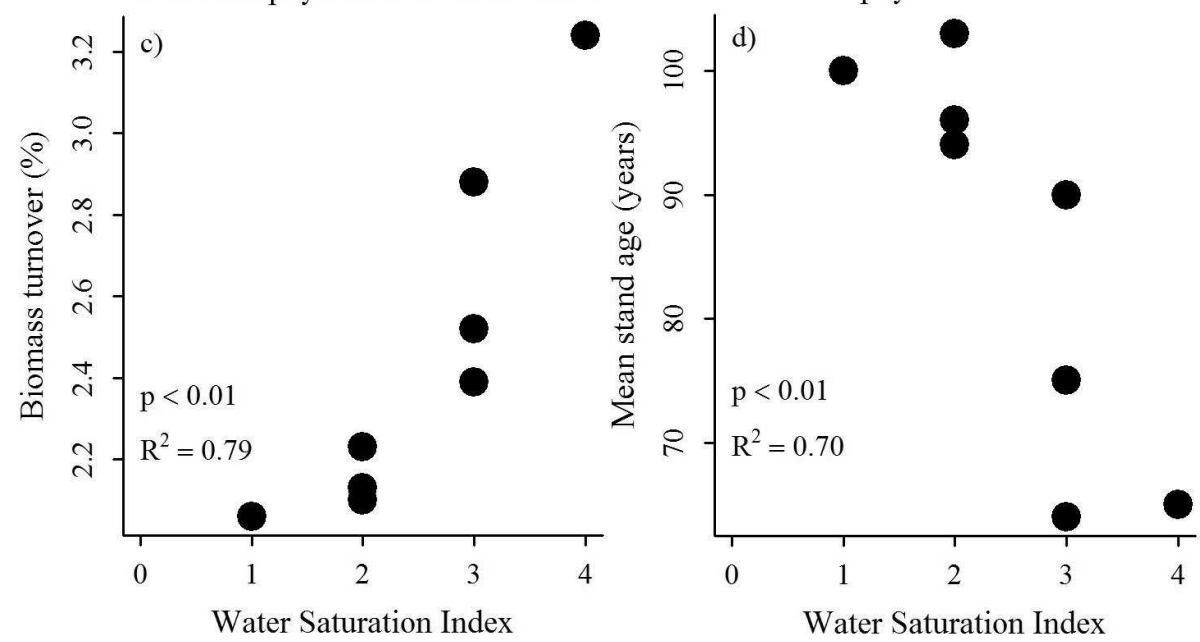

Fig. 5. Significant relations between the soil physical constraints index and (a) biomass turnover rates and (b) stand age, as well as the relation between soil water saturation index and (c) biomass turnover rates and (d) stand age.

seasonally flooded and waterlogged soils. This makes sense when we think that accelerating biomass turnover rates reduces the time for late successional development, resulting in forests with younger stand ages composed by trees species with shorter life spans. So far we do not have data on forest dynamics related to tree turnover considering mortality and recruitment rates, but our results show that the soil constraints, especially soil water saturation properties, accelerate forest dynamics in terms of higher biomass turnover.

However, in terms of aboveground wood biomass productivity, we cannot find relationships with physical soil properties or the water saturation index as we expected by our 


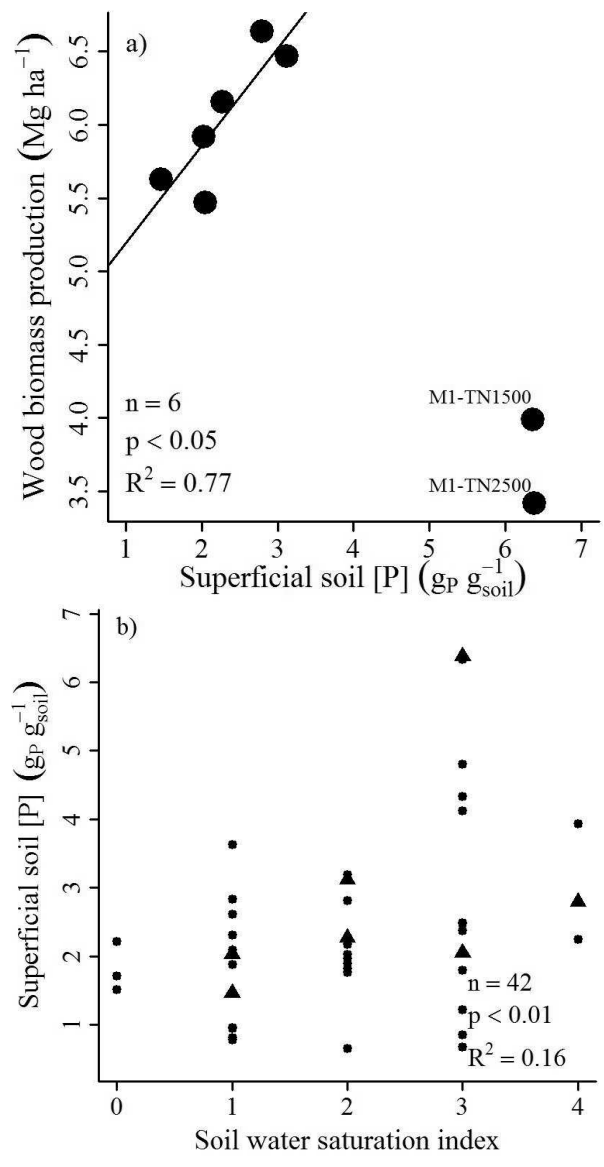

Fig. 6. (a) Significant relationship between available phosphorus at the soil surface and total aboveground wood productivity (AGWBP) excluding M01 plots, and (b) significant relationship between regionally available phosphorus at the soil surface and soil water saturation index, with triangles representing the eight sampled sites of this study.

working hypothesis. This is strange at first, since waterlogged sites with very evident hydromorphic soil features (higher water saturation index) indicate alternating waterlogging and drying very common in Plinthsols (Quesada et al., 2010, 2011), which may reduce oxidized iron atoms, making phosphorus available for plants (Chacon et al., 2006) and thus enhancing tree growth. This mechanism may be valid for the study region as we observe a trend between wood biomass productivity and plant-available phosphorus as well as the relation between the regional variation of available phosphorus and the water saturation index (Fig. 6). Therefore, we expected that enhanced hydromorphic features would result in more productive forests, since the water saturation index correlates with stand age and biomass turnover. On the other hand, these stands stocking on poorly developed soils (very hydromorphic, dense and shallow) present higher tree densities with smaller diameters when compared to forests growing on well-drained soils (Schietti, 2013), probably resulting in lower productivity by structural limitation.

Therefore we consider that soil constraints, especially water saturation, limit the structural development of the forest, maintaining a state of accelerated dynamics in terms of biomass turnover rates and reduced stand age. We suggest that harsher soil conditions may act as an environmental filter, creating a trade-off for fast-growing trees with shorter life-cycles, especially in the flooded or waterlogged sites, as in young successional stages of central Amazonian floodplain forests (Wittmann et al., 2006, 2010) and the bottomland flooded forests at the terra firme (Ferry et al., 2010). In this case we would expect lower wood densities at waterlogged sites and higher wood densities on well-drained soils characterized by slow-growing tree species (Gourlet-Fleury et al., 2011). Despite the low variation of mean wood density among our plots, we find a significant negative relationship between mean radial increments and wood density between the studied sites supporting this hypothesis.

Our results are very similar to those observed by Ferry et al. (2010) in French Guiana. They observe along a gradient from non-flooded hilltops down to seasonally flooded bottomlands a decrease of basal area, tree height and biomass storages and an increase in tree mortality, but only small differences in wood biomass productivity. The authors argue that bottomland areas, besides being more fertile, present lower biomass due to higher mortality rates associated to a poorly developed stand structure of the waterlogged soils. They discuss that this would favor fast-growing and lightdemanding species in the bottomland areas, compensating the wood biomass productivity. Our study area is very different from the well-known hilltop-bottomland terra firme forests, mainly because the nearest drainage is vertically very close to the surface even at the well-drained areas. But this mechanism might be also valid for the interfluvial landscape. Since increased soil constraints lead to higher biomass turnover rates, however, the poorly developed stand structure cannot compensate for the wood biomass productivity.

We raise the hypothesis that tree species in the studied interfluvial region characterized by complex hydrological conditions present varying climate-growth relationships between waterlogged and well-drained soils. This is a hypothesis which has to be tested in future studies. General global climate models predict a large impact for the Amazon Basin and its carbon stocks and uptakes, mainly due to shifts in the precipitation patterns and hydrological regimes (Dufresne et al., 2002; Betts et al., 2004; Cook et al., 2012). Changes in the Amazon hydrological cycle related to climate are mainly caused by the anomalies of sea surface temperature (SST) in the equatorial Pacific (Sombroek 2001; Foley et al., 2002; Marengo, 2004; Schöngart and Junk, 2007) and the tropical northern Atlantic (Marengo et al., 2008; Tomasella et al., 2011; Yoon and Zeng, 2010). The droughts of 2005 and 2010 were caused by SST anomalies of the tropical northern Atlantic Ocean (Marengo et al., 2008; Lewis et al., 2011) 
Table 6. Comparison between estimates of AGWB (in $\mathrm{Mg} \mathrm{ha}^{-1}$ ) and AGWBP (in $\mathrm{Mg} \mathrm{ha}^{-1} \mathrm{yr}^{-1}$ ) of old-growth forests from this study, with estimates from nutrient-rich (várzea) and nutrient-poor (igapó) floodplain forests, and non-flooded sites (paleovárzeas on ancient fluvial terraces and terra firme). The studies of Stadtler (2007), Oliveira (2010) and Schöngart et al. (2010) applied for the estimates of AGWB and AGWBP allometric models considering three independent parameters (diameter, tree height and wood density), while Chambers et al. (2001) and Malhi et al. (2004, 2006) use allometric models with only one (diameter) and two independent variables (diameter, wood density), respectively. SFC (in $\mathrm{Mg} \mathrm{m}_{\mathrm{BA}}^{-2}$ ) is the structural conversion factor relating AGWB to 1 square meter basal area (BA). Values are presented as means and standard deviation (with exception of those from Quesada et al., 2012). The results of other studies presented as Mg $\mathrm{C}$ were doubled to correspond to wood biomass.

\begin{tabular}{|c|c|c|c|c|}
\hline & Area & $\mathrm{SFC}\left(\mathrm{Mg} \mathrm{m}_{B A}^{-2}\right)$ & $\operatorname{AGWB}\left(\mathrm{Mg} \mathrm{ha}^{-1}\right)$ & $\operatorname{AGWBP}\left(\mathrm{Mg} \mathrm{ha}^{-1} \mathrm{yr}^{-1}\right)$ \\
\hline This Study & Purus-Madeira interfluvial region & $10.5 \pm 1.5$ & $241 \pm 69$ & $5.6 \pm 1.1$ \\
\hline Schöngart et al. (2010) & Central Amazonian várzea floodplains & $8.8 \pm 0.4$ & $235 \pm 7$ & $5.7 \pm 0.7$ \\
\hline Chambers et al. (2001) & Central Amazonian terra firme forests & - & $324 \pm 36$ & $4.1 \pm 0.7$ \\
\hline Malhi et al. $(2004,2006)$ & Southwestern Amazonian terra firme forests, Peru & $10.1 \pm 0.6$ & $270 \pm 40$ & $7.0 \pm 1.5$ \\
\hline Stadtler (2007) & Central Amazonian igapó floodplain & $8.9 \pm 1.6$ & $238 \pm 29$ & $3.6 \pm 1.2$ \\
\hline Oliveira (2010) & Paleovárzeas & $7.2 \pm 0.2$ & $192 \pm 14$ & $5.4 \pm 0.7$ \\
\hline Quesada et al. (2012) & Amazon forests & - & $139-458$ & $2.7-10.3$ \\
\hline
\end{tabular}

and affected between 2.5 and 3.2 million square kilometers in the Amazon Basin, respectively, including the interfluvial region between the Purus and Madeira rivers (Phillips et al., 2009; Lewis et al., 2011). Applying conventional tree-ring analysis and stable isotopes analysis for characteristic tree species from different ecotypes (evergreen and deciduous species) between well-drained and waterlogged soils in the interfluvial region, we predict that the vegetation period of tree species varies temporarily between different forest types depending on the soil physical constraints and the soil water regimes such as it was observed between floodplain forests and adjacent terra firme forests in central Amazonia with a shift of about 3 months between the growth rhythms of trees between both ecosystems (Schöngart et al., 2004, 2010).

As expected our results indicate a varying wood biomass productivity of $5.6 \pm 1.1 \mathrm{Mg} \mathrm{ha}^{-1} \mathrm{yr}^{-1}$ in the interfluvial landscape which seems to be more related to stand structure as to environmental parameters. In Table 6 we compare the results of AGWB and AGWBP in this study with other studies in different regions and forest ecosystems of the Amazon Basin. The AGWB stocks in the studied forests of the interfluvial landscape of the Purus-Madeira region are lower than in terra firme forests, but higher than in the nutrient-poor central Amazonian floodplain forests (igapó). Comparing the wood biomass productivity, our studied forests indicate a similar AGWBP as paleovárzeas $\left(5.4 \pm 0.7 \mathrm{Mg} \mathrm{ha}^{-1} \mathrm{yr}^{-1}\right)$ growing on ancient fluvial terraces (Irion et al., 2010) and the nutrient-rich várzea floodplain forests $\left(5.7 \pm 0.7 \mathrm{Mg} \mathrm{ha}^{-1} \mathrm{yr}^{-1}\right)$. In comparison to the seasonally flooded igapó $\left(3.6 \pm 1.2 \mathrm{Mg} \mathrm{ha}^{-1} \mathrm{yr}^{-1}\right)$ and the central Amazonian terra firme forests $\left(4.1 \pm 0.7 \mathrm{Mg} \mathrm{ha}^{-1} \mathrm{yr}^{-1}\right)$ our study indicates a higher AGWBP. Only the southwestern Amazonian terra firme forests with $7.0 \pm 1.5 \mathrm{Mg} \mathrm{ha}^{-1} \mathrm{yr}^{-1}$ seem to be more productive, however, as Malhi et al. (2004) applied allometric models, which do not consider tree height for the estimates of AGWB and AGWBP, leading to poten- tial biases in the biomass estimates (Schöngart et al., 2010; Feldpausch et al., 2012). Still, compared with recent estimates of the range of wood biomass productivity for Amazonia (2.7-10.3 $\mathrm{Mg} \mathrm{ha}^{-1} \mathrm{yr}^{-1}$ ) by Quesada et al. (2012), the forests of the interfluvial Purus-Madeira region present an above-average wood biomass productivity.

The obtained results on tree and stand tree ages, mean radial increment rates of dominant tree species and wood biomass productivity, and turnover rates of forests are essential information for the sustainable development of this particular region. Future scenarios predict increased deforestation rates in the next future in this interfluvial region due to the reconstruction and paving of the BR-319 Highway and following settlements and transformation of forests in lands for pasture and agriculture (Laurance et al., 2001; SoaresFilho et al., 2006; Davidson et al., 2012). The State Secretariat for the Environment and Sustainable Development (SDS) of Amazonas state and the Ministry for Environment (MMA) of the federal government implemented various areas of different protection categories within the interfluvial region to control land-use changes and to mitigate the emission of greenhouse gases caused by deforestation (Fearnside et al., 2009) as it is proposed by the United Nations collaborative initiative on reducing emissions from deforestation and forest degradation (REDD). The subsequent REDD+ initiative also considers the carbon stocks of intact forests in the background of conservation and sustainable management. However, the creation of conservation units requires a thorough scientific data base for designing a controlled monitoring of an ecologically and socio-economically sustainable development of this region. In this study we provide reliable estimates of stand ages, forest productivity and wood biomass turnover in relation to environmental factors, which is basic information, and criteria to decide which strategies regarding forest management and protection could be applied in this region considering land-use and climate changes. We 
suggest that forests on waterlogged sites should be excluded from any management practices since they present a limited structural development due to poorly structured soils. Forest management activities should be restricted to well-drained soils with more developed forests with a similar or even higher AGWBP of 5.6-6.5 Mg ha ${ }^{-1} \mathrm{yr}^{-1}$ than those forests on waterlogged or seasonally flooded soils. Furthermore, the tree-ring data can subside the initial development of applying site-specific and species-specific minimum logging diameter and cutting cycles for timber species in these environments as suggested by the GOL (growth-oriented logging) concept for the várzea floodplain forests (Schöngart, 2008) also considering regeneration dynamics and population structure.

Acknowledgements. We thank the Coordenação de Aperfeiçoamento de Pessoal de Nível Superior (CAPES) for financial support; the National Institute for Amazon Research - INPA, for providing all the infrastructure for the laboratories; the Project INPA/Max Planck and the INPA/MAUA group (Ecology, Monitoring and Sustainable Use of Wetlands) coordinated by M. T. F. Piedade for financing, providing laboratories and logistics; the PPBio/CENBAM coordinated by B. Magnusson and F. Costa for financing and providing all field infrastructure and the HIDROVEG project for logistical support for fields expeditions. We thank the reviewers L. Blanc, M. Larjavaara and M. van de Weg for their valuable comments and suggestions which substantially improved the quality of this study.

The service charges for this open access publication have been covered by the Max Planck Society.

Edited by: P. Stoy

\section{References}

Agência Nacional de Águas, http://hidroweb.ana.gov.br/ (last access: 28 February 2012), 2013.

Baker, T. R., Phillips, O. L., Malhi, Y., Almeida, S., Arroyo, L., Di Fiori, A., Erwin, T., Higuchi, N., Killeen, T. J., Laurance, S. G., Laurance, W. F., Lewis, S. L., Monteagudo, A., Neill, D. A., Vargas, P. N., Pitman, N. C. A., Silva, J. N. M., and Martínez, R. V.: Increasing biomass in Amazonian forest plots, Philos. T. Roy. Soc. B, 359, 353-365, 2004.

Betts, R. A., Cox, P. M., Collins, M., Harris, P. P., Huntingford, C., and Jones, C. D.: The role of ecosystem-atmosphere interactions in simulated Amazonian precipitation decrease and forest dieback under global climate warming, Theor. Appl. Climatol., 78, 157-155, 2004.

Brienen, R. J. W. and Zuidema, P. A.: Relating tree growth to rainfall in Bolivian rain forests: a test for six species using tree ring analysis, Oecologia, 146, 1-12, 2005.

Chacon, N., Silver, W. L., Dubinsky, E. A., and Cusack, D. F. Iron reduction and soil phosphorous solubilization in humid tropical forest soils: the roles of labile carbon pools and an electron shuttle compound, Biogeochemistry, 78, 67-84, 2006.

Chambers, J. Q., Santos, J., Ribeiro, R. J., and Higuchi, N.: Tree damage, allometric relationships, and above-ground net primary production in central Amazon forest, Forest Ecol. Manag., 152, 73-84, 2001

Chave, J., Condit, R., Aguilar, R., Hernandez, A., Lao, L., and Perez, L.: Error propagation and scaling for tropical forest biomass estimates, Philos. T. Roy. Soc. B, 359, 409-420, 2004.

Chave, J., Andalo, C., Brown, S., Cairns, M. A., Chambers, J. Q., Eamus, D., Fölster, H., Fromard, F., Higuchi, N., Kira, T., Lescure, J.-P., Nelson, B. W., Ogawa, H., Puig, H., Riéra, B., and Yamakura, T.: Tree allometry and improved estimation of carbon stocks and balance in tropical forests, Oecologia, 145, 87-99, 2005.

Cook, B., Zeng, N., and Yoon, J.-H.: will Amazonia Dry Out? Magnitude and Causes of Change from IPCC Climate Model Projections, Earth Interact., 16, 1-27, 2012.

Corlett, R. T.: Impact of warming on tropical lowland forests, Trends Ecol. Evol., 26, 606-613, 2011.

Davidson, E. A., Araújo, A. C., Artaxo, P., Balch, J. K., Brown, I. F., Bustamante, M. C. M., Coe, M. T., De Fries, R. S., Keller, M., Longo, M., Munger, J. W., Schroeder, W., Soares-Filho, B. S., Souza Jr., C. M., and Wofsy, S. C.: The Amazon basin in transition, Nature, 481, 321-328, 2012.

Donagema, G. K., Campos, D. V. B., Calderano, S., B., Teixeira, W. G., and Viana, J. H. M.: Manual de métodos de análise de solo, EMBRAPA SOLOS, Brazil, Rio de Janeiro, 2011.

Dufresne, J.-L., Friedlingstein, P., Berthelot, M., Bopp, L., Ciais, P., Fairhead, L., Le Treut, H., and Monfray, P.: On the magnitude of positive feedback between future climate change and the carbon cycle, Geophys. Res. Lett., 29, 43-1-43-4, doi:10.1029/2001GL013777, 2002.

Farr, T. G., Rosen, P. A., Caro, E., Crippen, R., Duren, R., Hensley, S., Kobrick, M., Paller, M., Rodriguez, E., Roth, L., Seal, D., Shaffer, S., Shimada, J., Umland, J., Werner, M., Oskin, M., Burbank, D., and Alsdorf, D.: The shuttle radar topography mission, Rev. Geophys., 45, RG2004, doi:10.1029/2005RG000183, 2007.

Fearnside, P. M., Graça, P. M. L. A., Keizer, E. W. H., Maldonado, F. D., Barbosa, R. I., and Nogueira, E. M.: Modelagem de desmatamento e emissões de gases de efeito estufa na BR-319, Revista Brasileira de Meteorologia, 24, 208-233, 2009.

Feldpausch, T. R., Banin, L., Phillips, O. L., Baker, T. R., Lewis, S. L., Quesada, C. A., Affum-Baffoe, K., Arets, E. J. M. M., Berry, N. J., Bird, M., Brondizio, E. S., de Camargo, P., Chave, J., Djagbletey, G., Domingues, T. F., Drescher, M., Fearnside, P. M., França, M. B., Fyllas, N. M., Lopez-Gonzalez, G., Hladik, A., Higuchi, N., Hunter, M. O., Iida, Y., Salim, K. A., Kassim, A. R., Keller, M., Kemp, J., King, D. A., Lovett, J. C., Marimon, B. S., Marimon-Junior, B. H., Lenza, E., Marshall, A. R., Metcalfe, D. J., Mitchard, E. T. A., Moran, E. F., Nelson, B. W., Nilus, R., Nogueira, E. M., Palace, M., Patiño, S., Peh, K. S.H., Raventos, M. T., Reitsma, J. M., Saiz, G., Schrodt, F., Sonké, B., Taedoumg, H. E., Tan, S., White, L., Wöll, H., and Lloyd, J.: Height-diameter allometry of tropical forest trees, Biogeosciences, 8, 1081-1106, doi:10.5194/bg-8-1081-2011, 2011.

Feldpausch, T. R., Lloyd, J., Lewis, S. L., Brienen, R. J. W., Gloor, M., Monteagudo Mendoza, A., Lopez-Gonzalez, G., Banin, L., Abu Salim, K., Affum-Baffoe, K., Alexiades, M., Almeida, S., Amaral, I., Andrade, A., Aragão, L. E. O. C., Araujo Murakami, A., Arets, E. J. M. M., Arroyo, L., Aymard C., G. A., Baker, T. R., Bánki, O. S., Berry, N. J., Cardozo, N., Chave, J., Comiskey, J. A., Alvarez, E., de Oliveira, A., Di Fiore, A., Djagbletey, G., 
Domingues, T. F., Erwin, T. L., Fearnside, P. M., França, M. B., Freitas, M. A., Higuchi, N., E. Honorio C., Iida, Y., Jiménez, E., Kassim, A. R., Killeen, T. J., Laurance, W. F., Lovett, J. C., Malhi, Y., Marimon, B. S., Marimon-Junior, B. H., Lenza, E., Marshall, A. R., Mendoza, C., Metcalfe, D. J., Mitchard, E. T. A., Neill, D. A., Nelson, B. W., Nilus, R., Nogueira, E. M., Parada, A., Peh, K. S.-H., Pena Cruz, A., Peñuela, M. C., Pitman, N. C. A., Prieto, A., Quesada, C. A., Ramírez, F., Ramírez-Angulo, H., Reitsma, J. M., Rudas, A., Saiz, G., Salomão, R. P., Schwarz, M., Silva, N., Silva-Espejo, J. E., Silveira, M., Sonké, B., Stropp, J., Taedoumg, H. E., Tan, S., ter Steege, H., Terborgh, J., TorelloRaventos, M., van der Heijden, G. M. F., Vásquez, R., Vilanova, E., Vos, V. A., White, L., Willcock, S., Woell, H., and Phillips, O. L.: Tree height integrated into pantropical forest biomass estimates, Biogeosciences, 9, 3381-3403, doi:10.5194/bg-9-33812012, 2012.

Ferry, B., Morneau, F., Bontemps, J.-D., and Freycon, V.: Higher treefall rates on slopes and waterlogged soils may result in lower stand biomass and productivity in a tropical rain forest, J. Ecol., 98, 106-116, 2010.

Flora do Brasil: Lista de Espécies da Flora do Brasil, http:// floradobrasil.jbrj.gov.br/2012/ (last access: 11 December 2012), 2012.

Foley, J. A., Botta, A., Coe, M. T., and Costa, M. H.: El Niño-Southern Oscillation and the climate, ecosystems and rivers of Amazonia, Global Biogeochem. Cy., 16, 1132, doi:10.1029/2002GB001872, 2002.

Girardin, C. A. J., Malhi, Y., Aragão, L. E. O. C., Mamani, M., Huaraca Huaso, W., Durand, L., Feeley, K. J., Rapp, J., SilvaEspejo, E., Silman, M., Salinas, M., and Whittaker, R. J.: Net primary productivity allocation and cycling of carbon along a tropical forest elevational transect in the Peruvian Andes, Glob. Change Biol., 16, 3176-3192, 2010.

Gourlet-Fleury, S., Rossi, V., Rejou-Mechain, M., Freycon, V., Fayolle, A., Saint-André, L., Cornu, G., Gérard, J., Sarrailh, J.-M., Flores, O., Baya, F., Billand, A., Fauvet, N., Gally, M., Henry, M., Hubert, D., Pasquier, A., and Picard, N.: Envionmental filtering of dense-wooded species controls above-ground biomass stores in African Moist Forests, J. Ecol., 99, 981-990, 2011.

IBGE, Recursos naturais e meio ambiente: uma visão do Brasil, Instituto Brasileiro de Geografia e Estatística, Brasil, 2nd ed, 1997.

Instituto Nacional de Pesquisas da Amazônia (INPA), Manaus, Brazil: Programa de Pesquisa em Biodiversidade - PPBio, http: //www.ppbio.inpa.gov.br (last access: 20 February 2012), 2012.

Irion, G., de Mello, J. A. S. N., Morais, J., Piedade, M. T. F., Junk, W. J., and Garming, L.: Development of the Amazon valley during the Middle to Late Quaternary: sedimentological and climatological observations, in: Central Amazonian floodplain forests: Ecophysiology, biodiversity and sustainable management, edited by: Junk, W. J., Piedade, M. T. F., Wittmann, F., Schöngart, J., and Parolin, P., Ecological Studies, Springer, Berlin/Heidelberg/New York, 27-42, 2010.

Junk, W. J., Piedade, M. T. F., Schöngart, J., Cohn-Haft, M., Adeney, J. M., and Wittmann, F.: A Classification of Major Naturally-Occurring Amazonian Lowland Wetlands, Wetlands, 31, 623-640, 2011.

Kirby, K. R. and Potvin, E.: Variation in carbon storage among tree species: Implications for the managements of a small-scale carbon sink project, Forest Ecol. Manag., 246, 208-221, 2007.
Laurance, W. F., Cochrane, M. A., Bergen, S., Fearnside, P. M., Delamônica, P., Barber, C., D’ Angelo, S., and Fernandes, T.: The future of the Brazilian Amazon, Science, 291, 438-439, 2001.

Lewis, S. L., Brando, P., Phillips, O. L., van der Heijden, G. M. F., and Nepstad, D.: The 2010 Amazon Drought, Science, 331, p. 554, 2011.

Magnusson, W. E., Lima, A. P., Luizão, R., Luizão, F., Costa, F. R. C., Castilho, C. V., and Kinupp, V. R.: RAPELD: a modification of the Gentry method for biodiversity surveys in long-term ecological study sites, Biota Neotropica, 5, 1-6, 2005.

Malhi, Y., Baker, T. R., Phillips, O. L., Almeida, S., Alvarez, E., Arroyo, L., Chave, J., Czimczik, C. I., Di Fiori, A., Higuchi, N., Killeen, T. J., Laurance, S. G., Laurance, W. F., Lewis, S. L., Montoya, L. M. M., Monteagudo, A., Neill, D. A., Vargas, P. N., Patiño, S., Pitman, N. C. A., Quesada, C. A., Salomão, R., Silva, J. N. M., Lezama, A. T., Martínez, R. V., Terborgh, J., Vinceti, B., and Lloyd, J.: The above-ground coarse wood productivity of 104 Neotropical forest plots, Glob. Change Biol., 10, 563-591, 2004.

Malhi, Y., Wood, D., Baker, T. R., Wright, J., Phillips, O. L., Cochrane, T., Meir, P., Chave, J., Almeida, S., Arroyo, L., Higuchi, N., Killeen, T. J., Laurance, S. G., Laurance, W. F., Lewis, S. L., Monteagudo, A., Neill, D. A., Vargas, P. N., Pitman, N. C. A., Quesada, C. A., Salomão, R., Silva, J. N. M., Lezama, A. T., Terborgh, J., Martínez, R. V., and Vinceti, B.: The regional variation of aboveground live biomass in old-growth Amazonian forest, Glob. Change Biol., 12, 1-32, 2006.

Marengo, R.: Interdecadal variability and trends of rainfall across the Amazon basin, Theor. Appl. Climatol., 78, 79-96, 2004.

Marengo, J. A., Nobre, C. A., Tomasella, J., Cardoso, M. F., and Oyama, M. D.: Hydro-climatic and ecological behaviour of the drought of Amazonia in 2005, Philos. T. R. Soc. Lon. B, 363 , 1773-1778, 2008.

Martins, D. L., Schietti, J., Luizão, F. J., Phillips, O., Andrade, A., Castilho, Andrade, A., C. V., Laurance, S.G., Oliveira, A., Toledo, J. J., Lugli, L.F. Mendoza, E.M.O., Feldpausch, T. R., and Quesada, C. A. Soil induced changes on vegetation drive necromass stocks in Central Amazonia, Plant Ecology Diversity, special ed., in review, 2013.

Miranda, E. E.: Brasil em Relevo, Campinas, Embrapa, Monitoramento por Satélite, available in: Brasil em Relevo, Embrapa monitoramento por satélite, http://www.relevobr.cnpm.embrapa. br (last access: 29 March 2013), 2005.

Moulatlet, G. M.: A importância de condições hidrológicas na distribuição e conservação de plantas herbáceas de sub-bosque em florestas amazônicas: uma contribuição em escala regional, M Sc. Thesis, Brazil, National Institute for Amazon Research, 51 pp., 2010.

NASA Jet Propulsion Laboratory, California Institute of Technology: US Geological Survey, http://www.usgs.gov (last access: 29 February 2012), 2012.

Nogueira, E. M., Fearnside, M. P., Nelson, B. N., Barbosa, R. I., and Keizer, E. W. H.: Estimates of forest biomass in the Brazilian Amazon: new allometric equations and adjustments to biomass from wood-volume inventories, Forest Ecol. Manag., 256, 18531867, 2008a.

Nogueira, E. M., Nelson, B. W., Fearnside, P. M., França, M. B., and Oliveira, A. C. A.: Tree height in Brazil's arc of deforestation: 
shorter trees in south and southwest imply lower biomass, Forest Ecol. Manag., 255, 2963-2972, 2008b.

Oliveira, C. L.: Estimativas da dinâmica de carbono na biomassa lenhosa de terra firme na Reserva de Desenvolvimento Sustentável Amanã por métodos dendrcronológicos, M.Sc. thesis, National Institute for Amazon Research, 43 pp., 2010.

Phillips, O. L., Aragão, L. E. O. C., Lewis, S. L., Fischer, J. B., Lloyd, J., López-Gonzales, G., Malhi, Y., Monteagudo, A., Peacock, J., Quesada, C. A., vam-der-Heijden, G., Almeida, S., Amaral, L., Arroyo, L., Aymard, G., Baker, T. R., Bánki, O., Blanc, L., Bonal, D., Brando, P., Chave, J., Oliveira, A. C. A., Cardozo, N. A., Czimczik, C. I., Feldpausch, T. R., Freitas, M. A., Gloor, E., Higushi, N., Jiménez, E., Lloyd, G., Meir, P., Mendoza, P., Morel, A., Neill, D. A., Nepstad, D., Patiño, S., Peñuela, M. C., Prieto, A., Ramírez, F., Schwartz, M., Silva, J., Silveira, M., Thomas, A. S., ter-Steege, H., Stropp, J., Vásquez, R., Zelazowski, P., Dávila, E. A., Andelman, S., Andrade, A., Chao, K. J., Erwin, T., Di-Fiore, A., Honório, E., Keeling, H., Kileen, T. J., Laurance, W. F., Cruz, A. P., Pitman, N. C. A., Vergas, P. N., Ramírez-Angulo, H., Rudas, A., Salamão, R., Silva, N., Terborgh, J., and Torres-Lezama, A.: Drought sensitivity of the Amazon forest, Science, 323, 1344-1347, 2009.

Quesada, C. A., Lloyd, J., Schwarz, M., Patiño, S., Baker, T. R., Czimczik, C., Fyllas, N. M., Martinelli, L., Nardoto, G. B., Schmerler, J., Santos, A. J. B., Hodnett, M. G., Herrera, R., Luizão, F. J., Arneth, A., Lloyd, G., Dezzeo, N., Hilke, I., Kuhlmann, I., Raessler, M., Brand, W. A., Geilmann, H., Moraes Filho, J. O., Carvalho, F. P., Araujo Filho, R. N., Chaves, J. E., Cruz Junior, O. F., Pimentel, T. P., and Paiva, R.: Variations in chemical and physical properties of Amazon forest soils in relation to their genesis, Biogeosciences, 7, 1515-1541, doi:10.5194/bg-7-15152010, 2010.

Quesada, C. A., Lloyd, J., Anderson, L. O., Fyllas, N. M., Schwarz, M., and Czimczik, C. I.: Soils of Amazonia with particular reference to the RAINFOR sites, Biogeosciences, 8, 1415-1440, doi:10.5194/bg-8-1415-2011, 2011.

Quesada, C. A., Phillips, O. L., Schwarz, M., Czimczik, C. I., Baker, T. R., Patiño, S., Fyllas, N. M., Hodnett, M. G., Herrera, R., Almeida, S., Alvarez Dávila, E., Arneth, A., Arroyo, L., Chao, K. J., Dezzeo, N., Erwin, T., di Fiore, A., Higuchi, N., Honorio Coronado, E., Jimenez, E. M., Killeen, T., Lezama, A. T., Lloyd, G., López-González, G., Luizão, F. J., Malhi, Y., Monteagudo, A., Neill, D. A., Núñez Vargas, P., Paiva, R., Peacock, J., Peñuela, M. C., Peña Cruz, A., Pitman, N., Priante Filho, N., Prieto, A., Ramírez, H., Rudas, A., Salomão, R., Santos, A. J. B., Schmerler, J., Silva, N., Silveira, M., Vásquez, R., Vieira, I., Terborgh, J., and Lloyd, J.: Basin-wide variations in Amazon forest structure and function are mediated by both soils and climate, Biogeosciences, 9, 2203-2246, doi:10.5194/bg-9-2203-2012, 2012.

R Core Team.: R: A language and environment for statistical computing, http://www.R-project.org/ (last access: 12 October 2013), 2013.

Rennó, C. D., Nobre, A. D., Cuartas, L. A., Soares, J. V., Hodnett, M. G., Tomasella, J., and Waterloo, M. J.: HAND, a new terrain descriptor using SRTM-DEM: Mapping terra-firme rainforest environments in Amazônia, Remote Sens. Environ., 112, 3469-3481, 2008.
Rosetti, D. F., Toledo, P. M., and de-Góes, A. M.: New geological framework for Western Amazonia (Brazil) and implications for biogeography and evolution, Quaternary Res., 63, 78-89, 2005.

Schietti, J.: Interações entre floresta, chuva e solo em áreas de lençól freático superficial na Amazônia Central, Ph.D Thesis, National Institute for Amazon Research, 144 pp., 2013.

Schöngart, J.: Growth Oriented Logging (GOL): A new concept towards sustainable forest management in Central Amazonian várzea floodplains, Forest Ecol. Manag., 256, 46-58, 2008.

Schöngart, J. and Junk, W. J.: Forecasting the flood-pulse in central Amazonia by ENSO-indices, J. Hydrol., 335, 124-132, 2007.

Schöngart, J., Piedade, M. T. F., Ludwigshausen, S., Horna, V., and Worbes, M.: Phenology and stem-growth periodicity of tree species in Amazonian floodplain forests, J. Trop. Ecol., 18, 581597, 2002.

Schöngart, J., Junk, W. J., Piedade, M. T. F., Ayres, J. M., Hüttermann, A., and Worbes, M.: Teleconnection between tree growth in the Amazonian floodplains and the El Niño Southern Oscillation effect, Glob. Change Biol., 10, 683-692, 2004.

Schöngart, J., Piedade, M. T. F., Wittmann, F., Junk, W. J., and Worbes, M.: Wood growth patterns of Macrolobium acaciifolium (Benth.) Benth.(Fabaceae) in Amazonian black-water and whitewater floodplain forests, Oecologia, 145, 454-461, 2005.

Schöngart, J., Wittmann, F., and Worbes, M.: Biomass and NPP of Central Amazonian floodplain forests, in: Amazonian floodplainforests: Ecophysiology, biodiversity and sustainable management, edited by: Junk, W. J., Piedade, M. T. F., Wittmann, F., Schöngart, J., and Parolin, P., Ecological Studies, Springer, Berlin/Heidelberg/New York, 347-388, 2010.

Schöngart, J., Arieira, J., Felfili Fortes, C., Cezarine de Arruda, E., and Nunes da Cunha, C.: Age-related and stand-wise estimates of carbon stocks and sequestration in the aboveground coarse wood biomass of wetland forests in the northern Pantanal, Brazil, Biogeosciences, 8, 3407-3421, doi:10.5194/bg-8-3407-2011, 2011.

Soares-Filho, B. S., Nepstad, D. C., Curran, L. M., Cerqueira, G. C., Garcia, R. A., Azevedo Ramos, C., Voll, E., McDonald, A., Lefebvre, P., and Schlesinger, P.: Modelling conservation in the Amazon basin, Nature, 440, 520-523, 2006.

Sombroek, W.: Spatial and temporal patterns of Amazon rainfall, Ambio, 30, 388-396, 2001.

Stadtler, E.: Estimativas de biomassa lenhosa, estoque e seqüestro de carbono acima do solo ao longo do gradiente de inundação em uma floresta de igapó alagada por água preta na amazônia central, M. Sc. thesis, National Institute for Amazon Research, Brazil, 57 pp., 2007.

The New York Botanical Garden: International Plant Science Center - The C. V. Starr Virtual Hebarium, http://sciweb.nybg.org/ science2/vii2.asp (last access: 12 November 2012), 2012.

Tomasella, J., Borma, L. S., Marengo, J. A., Rodriguez, D. A., Cuartas, L. A., Nobre, C. A., and Prado, M. C. L.: The droughts of 1996-1997 and 2004-2005 in Amazonia: hydrological response in the river main stem, Hydrol. Process., 25, 1228-1242, 2011.

Wittmann, F., Schöngart, J., Montero, J. C., Motzer, T., Junk, W. J., Piedade, M. T. F., Queiroz, H. L., and Worbes, M.: Tree species composition and diversity gradients in white-water forests across the Amazon Basin, J. Biogeogr., 33, 1334-1347, 2006.

Wittmann, F., Schöngart, J., and Junk, W. J.: Phytogeography, species diversity, community structure and dynamics of central Amazonian floodplain forests, in: Amazonian floodplain forests: 
Ecophysiology, biodiversity and sustainable management, edited by: Junk, W. J., Piedade, M. T. F., Wittmann, F., Schöngart, J., and Parolin, P., Ecological Studies, vol. 2010, Springer Verlag, Dordrecht, Heidelberg, London, New York, 61-102, 2010.

Worbes, M.: The forest ecosystem of the floodplains, in: The Central Amazon Floodplains. Ecology of a Pulsing System, edited by Junk, W. J., Springer Verlag, Berlin, Heidelberg, 223-266, 1997.
Worbes, M.: One hundred years of tree-ring research in the tropics - a brief history and an outlook to future challenges, Dendrochronologia, 20, 217-231, 2002.

Yoon, J.-H. and Zeng, N.: An Atlantic influence on Amazon Rainfall, Clim. Dynam., 34, 249-264, 2010. 